\title{
As origens emocionais da evasão: apontamentos etnográficos a partir da Educação de Jovens e Adultos
}

The emotional origins of school dropout: ethnographic notes from Youth and Adult Education

\author{
Alef de Oliveira Lima* \\ *Universidade Federal do Rio Grande do Sul - Porto Alegre, RS, Brasil \\ Doutorando em Antropologia Social \\ aleflimaufrgs@gmail.com \\ https://orcid.org/0000-0002-7390-3679
}




\title{
Resumo
}

O presente texto trata das origens emocionais da evasão escolar, analisadas a partir do material etnográfico coletado por meio da observação participante no contexto da Educação de Jovens e Adultos do Colégio de Aplicação (CAp./UFRGS). Possui como objetivo compreender o espelhamento emocional no fenômeno do abandono escolar, verificando-o nas formas diversas e sensíveis que ele ocorre. Em meio a diálogos e relatos, o texto adentra na densidade etnográfica presente em um momento específico da pesquisa de campo, focalizando, ainda, a dimensão corporal e política que é inscrita na "escolarização tardia" dos sujeitos. Essas experiências sentimentais, entendidas enquanto afetos irresolutos, são conformadas em backgrounds morais que orientam as decisões dos interlocutores, fazendo com que a evasão seja ao mesmo tempo ética, pessoal e contrapolítica. Desse modo, os resultados interpretativos desse primeiro fôlego ao diário de campo do autor apontam para o fato de que a desistência é algo emocional e politicamente importante.

Palavras-chave: evasão; EJA; antropologia das emoções; etnografia.

\begin{abstract}
The present text deals with the emotional origins of school dropout, analyzed from the ethnographic material collected through participant observation in the context of the Youth and Adult Education of the College of Application (CAp./UFRGS). It aims to understand the emotional mirroring in the phenomena of school drop-out, verifying it in the diverse and sensitive forms that it occurs. In the midst of dialogues and reports, the text penetrates the ethnographic density present at a specific moment of the field research, also focusing on the corporal and political dimension that is inscribed in the "late schooling" of the subjects. These sentimental experiences, understood as unresolved affections, are shaped in moral backgrounds that guide the decisions of the interlocutors, making evasion both ethical, personal and counterpolitical. Thus, the interpretive results of this first breath to the author's field diary point to the fact that giving up is something emotional and politically important.
\end{abstract}

Keywords: evasion; YAE; anthropology of emotions; ethnography. 


\section{Introdução ${ }^{1}$}

No dia 24 de junho de 2016, fazia três meses que havia iniciado meu trabalho de campo junto aos estudantes da Educação de Jovens e Adultos (EJA) do Colégio de Aplicação (CAp.) da Universidade Federal do Rio Grande do Sul (UFRGS). Mais exatamente, completavam-se 12 semanas que andava rondando os corredores, acompanhando as aulas dos professores e conversando com os alunos para, de início, estabelecer uma pesquisa exploratória com um tema completamente distinto do que atualmente venho pensando. Desse modo, as considerações tecidas neste artigo dizem respeito a um momento etnográfico específico da pesquisa: aquele instante entre uma definição apriorística do tema e conceitos do etnógrafo e sua imersão na vida dos interlocutores e nos lugares que ocupam em certa topografia social.

Nesse dia, particularmente frio, lembro-me de ter sido apresentado a uma das professoras da EJA. Não recordo ao certo o que conversamos, mas ambos estávamos sentados em um banco de madeira defronte à recepção, na entrada interna do prédio. A docente falava-me de sua pesquisa de doutorado, que pelo que pude entender ainda se encontrava em execução, e talvez tenha ficado curiosa em saber o que eu fazia ali, em diferentes momentos - no acompanhamento das aulas, no refeitório, no antes, durante e depois da sala da aula: uma etnografia. Ela, a professora, relatou-me sua tese sobre os motivos da evasão. Dizia:

Certa vez, trabalhei em uma escola cuja entrada dava numa praça, com barracas e lanchonetes bem diversas. Já ensinava na EJA. Eu e outros professores ficávamos chocados com o número alto de evasão. Então, em uma pesquisa meio informal, conversando com os alunos, descobrimos que eles vinham para o colégio, mas ficavam estacionados e entretidos na praça, lanchando e papeando. (Diário de campo, sexta-feira, 24 de junho de 2016).

A impressão que tive, naquela hora, com a exposição da professora, era de que a evasão, para ela, não era explicável pelo abandono do alunado, mas sim por

1 O presente trabalho foi realizado com apoio da Coordenação de Aperfeiçoamento de Pessoal de Nível Superior - Brasil (Capes) - Código de Financiamento 001. 
outro viés: a contestação visível de que a praça, como um lugar, desempenhava uma miríade de interesses, "mais atraentes" do que a oferta do ensino da escola. Era simples, muito simples. A evasão é localmente situada e o espaço geográfico onde a escola se localizava era, em certo sentido, o responsável por ela.

Os alunos, por sua vez, como "engajados" no seu desinteresse, localizavam na praça sua linha de fuga. Aqui, explicita-se argumento plausível, embora provisório. No caso do Colégio de Aplicação, escola que fica dentro da UFRGS, alocada em um campus que é fronteiriço entre Porto Alegre e Viamão, e que possui alunos de toda a região metropolitana, como se valer da localização geográfica?

A proposta é menos levantar motivos e alinhá-los com justificativas já comuns no campo da educação - como desinteresse, rotinas de trabalho sufocantes, ausência de escolas para suprir a demanda (Neri, 2009) - e sim refletir sobre o espelhamento das emoções no fenômeno da evasão. Tal exercício se fará a partir das incursões teóricas sobre a corporeidade em Csordas (2008) e a abordagem contextualista da antropologia das emoções, delimitada pelas autoras Lila Abu-Lughod e Catherine Lutz (1990), assim como as ideias de Andrew Beatty (2010) sobre os afetos no corpus dos dados etnográficos. Dessa maneira, quando menciono a palavra "evasão", suponho tanto um movimento (abandono) quanto um sujeito desse movimento (o evadido) em sua corporeidade e suas emoções.

Quero, ainda, enfatizar como essa problemática por vezes tem sido distribuída numa triangulação escola, aluno e evasão, sem que se reintegrem outros elementos igualmente importantes: 1) os sentimentos da evasão; 2) o corpo do evadido; 3) a escolarização na história emocional dos sujeitos. Esses aspectos são dinâmicos e indissociáveis, e serão levados em consideração no presente artigo.

No período particular entre os meses de abril e de junho de 2016, na fase crucial do campo, ${ }^{2}$ não fazia sentido pesquisar a dinâmica do abandono escolar. A evasão não falou mais alto enquanto temática relevante e meus interlocutores, evadidos, logicamente não me possibilitaram uma imersão mais profunda. Naquele momento inicial, perambulava pelas aulas das três turmas (EM1, EM2,

2 Trata-se da etapa exploratória da pesquisa de campo que consistiu na minha dissertação de mestrado. 
EM3) da EJA. Cada uma representa um ano do ensino médio, agora dividido semestralmente. Um estudante que não tem o ensino médio completo, antigo secundário, pode fazer em um ano e meio as três séries.

Com isso, me afeiçoei muito rapidamente à EM3. Minha inserção foi mais fácil já que, como iriam concluir, os estudantes dessa turma, em especial, estavam acostumados a ter um bolsista ou estagiário de olho na aula. Nela, localizei um ponto de observação: a etnografia seria feita a partir da ótica vivencial dos estudantes e o maior dispositivo metodológico que eu encontrei foi me tornar mais um aluno, dispondo-me a fazer os exercícios e as provas e a participar nos trabalhos de equipe. Estar à disposição para escutar os meus interlocutores e ouvi-los no mesmo patamar das atividades que desempenham, tomando como conduta metodológica as ideias defendidas por Tim Ingold (2015, p. 219, tradução minha), ao explicitar que:

[...] a antropologia é uma indagação generosa, aberta, comparativa e não obstante crítica das condições e dos potenciais na vida humana no único mundo que habitamos. É generosa, porque se funda na vontade tanto de escutar como de responder ao que outros têm a dizer.

Consequentemente, esses primeiros contatos foram para me ambientar e fazer o campo. Capiná-lo, traçar relações sociais e entender a peculiaridade do meu empreendimento etnográfico. Os meus interlocutores sempre estão se renovando: a EM3 vai embora e esse exercício vai ter que se repetir criativamente. Decorre que, após esse período inicial, voltei-me para a EM1 - uma turma estreitamente variável (mais fechada e que foi o pontapé inicial para se pensar a evasão).

De tempos em tempos, quando decidi acompanhá-los mais longamente, notava que as pessoas com que eu conversava apareciam em alguns dias, e em outros, não. A situação se evidenciava mais na hora da chamada: de 25 alunos, apenas 15 ou 16 iam respondendo. Para os estudantes, "tinha dia que dava para vir e tinha dia que não" (muitos eram pais e mães, filhos e filhas de alguém). A escolarização era apreciada, considerada importante, mas, nos momentos de aperto financeiro e familiar, podia ser deixada de lado.

Só depois de um semestre inteiro, quando reencontrei a EM1, transformada agora em EM2, pude perceber - ou melhor, analisar - as raízes sentimentais 
que são atraídas e conjugadas com o fenômeno da evasão, aqui entendidas pelo laço da micropolítica das emoções (Abu-Lughod; Lutz, 1990). Nesse retorno, que ocorreu com atraso devido à submissão do meu projeto de pesquisa e sua avaliação pela Comissão de Pesquisa (Compesq) do colégio, fui direcionando a pesquisa de campo para o acompanhamento progressivo da EM2 ${ }^{3}$ a fim de presenciar sua transmutação em EM3 - e disso decorre a principal fonte dos dados etnográficos.

As origens sentimentais da evasão constituem uma hipótese, no limite, um procedimento intuitivo para compreender diacronicamente os acontecimentos que ocorrem quando a EM2 era ainda a EM1. Os relatos e falas recolhidos são, portanto, dos colegas daqueles que foram se ausentando das aulas. Foram eles, e não eu, que perceberam a evasão como um problema. E sobre esse assunto, teceram considerações emblemáticas desses irresolutos afetos que fazem da desistência da escolarização algo politicamente importante.

\section{O sentido político da evasão e os seus sentimentos}

A noção de político aqui tomada não é vinculada a um espectro necessariamente amplo, ou a um significado estrito daquilo que se presume com o adjetivo "político". Os alunos, alguns deles, não sentem a evasão no escopo da EJA enquanto problemática de uma política educacional que reside na pactuação das esferas municipais, estaduais e federais. O sentido político da evasão é o efeito de refluxo de um corpo presente, que no decorrer dos meses torna-se ausente. Explico-me: os estudantes sentem a desistência de seus colegas quando eles faltam um, dois, três dias.

A ausência prolongada de alguém é remetida ao abandono, e é justamente a ausência desse alguém com quem se convivia que se desdobra numa

3 Agradeço a indicação da coordenadora da EJA naquele momento, que mencionou como algo interessante de ser feito, compreender a transmutação de uma turma, ver suas transformações no acompanhamento sequencial de suas aulas, atividades, avaliações e dinâmicas. O que realmente se mostrou de grande valia etnográfica, o ponto de observação progressivo ia se modificando, conforme traçava o campo de relações sociais com meus interlocutores, eles mesmos, convocavam-me a mudar o prisma do meu olhar. 
interpelação ética. Como ele desistiu e eu vou continuar? ${ }^{4}$ De certa maneira, a indagação mexe com as trajetórias dos estudantes que imaginam as situações e justificativas da desistência desse outro. A alteridade desse corpo não mais presente faz com que a ausência se personifique num jogo ético em que os sujeitos repensam suas próprias motivações para continuar. O filósofo francês Lévinas (1987, p. 19) deslinda essa ideia de uma ética sempre iniciada a partir a outro ao afirmar que "[...] a aventura existencial do próximo importa ao Eu antes que a sua própria".

Em todo o caso, a dimensão corporal sempre é evocada para nomear os afetos que subsidiam a evasão. Em uma noite fria, já mais de dez horas, no momento da saída, uma das minhas interlocutoras, Carol, ${ }^{5}$ me oferece uma carona em sua bicicleta. Um pouco receoso de percorrer oito quilômetros em uma avenida movimentada, disputando espaço com carros e motos, aceito. No percurso, Carol e eu fomos papeando. Ela estava um pouco esbaforida de tanto pedalar e eu sempre de olho no trânsito (segurando-me na traseira) e nos movimentos que ela executava no guidão da bike. Na nossa conversa veio à tona o tema da evasão e disso depreende-se o que ela me confidenciou:

Ah, Alef. Uma pessoa deixa de frequentar as aulas por desânimo. Digo porque muitas vezes senti vontade de desistir. Tu passas o dia trabalhando e quando chega a noite tem que trabalhar mais. Nosso corpo cansa, sabe? Fico com preguiça e vou desanimando. Chega a hora de ir para aula e você sente uma moleza e um cansaço e pronto, você não vai à aula. (Diário de campo, quinta-feira, 10 de novembro de 2017).

O desânimo é um afeto conjuntado com a moleza do corpo e a preguiça. Sigo essa pista e dela retiro um aspecto importante das emoções sentidas por quem decidiu

4 Sobre esse aspecto é interessante mencionar a raiz etimológica da palavra "evasão": do latim evasio, de evadere, "fugir, escapar", de ex-, "fora", mais vadere, "ir, caminhar". O jogo dos verbos fugir e escapar, ir e caminhar sugere um movimento andante, preocupado com um distanciamento, com uma fuga e deixa em relevo a dimensão angustiante dessa decisão. Ver: http://origemdapalavra.com.br/palavras/evasao/ (acesso em 28/04/2017).

5 Todos os nomes utilizados nesse trabalho são fictícios e visam garantir o direito de não identificação assinalado no Termo de Consentimento Livre e Esclarecido. 
evadir: elas, nos termos das antropólogas Janis Jenkins e Martha Valiente (1994, p. 165, tradução minha), representam "as estratégias psicossomáticas do corpo na construção emocional e na percepção dessas sensações". O abandono é sentido como uma convocatória das rotinas cansativas de um dia cheio. Nesse aspecto, liga-se ao desânimo que retira uma vivacidade do corpo em nome de uma sensação de exaustão.

Reitero a fala de Carol mais uma vez: os afetos podem ser subsumidos na base de um envolvimento experiencial porque, dentro da abordagem etnográfica, definem modos de engajamento com o mundo (Barbalet, 2000), demonstram os graus de reciprocidade, funcionam na forma de uma linguagem (Mauss, 1979). A hipótese então continua válida, na medida em que credito aos comentários de Carol o valor de uma compreensão imersiva dentro da "cultura afetiva" (Le Breton, 2009), ou seja, se compartilha entre Carol e os demais colegas da sua turma um conjunto mais ou menos homogêneo e mais ou menos delimitado de sentimentos inteligíveis.

A evasão tem um perfil codificado dentro da instituição. Os estudantes que desejam fazer parte do Colégio de Aplicação passam por um sorteio e, antes, devem candidatar-se às vagas por meio de um edital público. Esse processo gera uma efervescência; segundo relatos, é um momento em que os pais e os possíveis alunos se aglomeram para ouvir o nome de seu filho, em um espaço delimitado - geralmente, o pequeno estacionamento que existe próximo ao portão de entrada. Na EJA, esse frisson não ocorre da mesma maneira. Perguntei à coordenadora - à época - se, de fato, também existia essa mesma dinâmica, ao que ela me responde:

- A dinâmica que tu relatas não ocorre na EJA. Ultimamente, nós temos um histórico em que todos os inscritos são chamados, pelo menos como suplentes. Assim, não temos tanta disputa e nem vagas remanescentes que não são, em algum momento, ocupadas. Parte disso se deve à evasão. As [disputas por] vagas remanescentes na educação infantil, [no ensino] fundamental e médio nos turnos regulares são bem mais acirradas. Você tem dez ou quinze candidatos para uma vaga.

Pergunto se tem algum aluno da EM3 do semestre passado que vai repetir. Ela confere uma planilha, senta-se e ajeita os óculos. Diz que todos aqueles que reprovaram, num total de cinco alunos (a EM3 daquele momento ainda era uma 
turma relativamente pequena), todos tinham sido reprovados por evasão. Eles acabaram perdendo a vaga. Segundo a professora, a legislação prevê apenas 25 por cento de faltas. Qualquer um que ultrapasse esse percentual perde a matrícula. (Diário de campo, segunda-feira, 10 de outubro de 2016).

Dessa forma, decorre que a evasão é um processo contínuo de desengajamento. Não se trata de uma decisão tomada de última hora, em que as diversas variáveis coagem o sujeito a assumir sua posição sem mais nem menos. Instaurada no corpo, diariamente repensada, a evasão é coadunada em faltas sucessivas, marcando não apenas uma decisão intencional, mas também um produto dinâmico de sentimentos que às vezes foram represados na esteira de uma escolarização imediatamente posterior. Nesse ponto, um trecho de uma entrevista com Carol é esclarecedor. Ela remonta o primeiro retorno depois de passar mais de 19 anos fora da escola, bem antes de ingressar no CAp.:

Quando eu fiz uma pergunta para a professora, não lembro, não recordo se era uma professora ou um professor, não lembro. Eu disse assim: "Ai, que matérias difíceis. Que matéria difícil." Ela falou [a professora] assim: "Ah... [com ar de desprezo]. Isso é matéria de quarta série." Eu fiquei com uma vergonha. Não fui mais. E ao mesmo tempo eu estava trabalhando. Eu chegava em casa estressada. Eu ia e vinha de bicicleta. Como tu sabes [fala olhando para mim e confirmo entre um movimento com a cabeça e um gole de café]. Para tudo que é lado. Eu chegava em casa muito estressada. No dia que ela [a professora] falou isso, meu filho... [hesitação e correção]. Tenho um filho menor, na época ele era menor ainda [referência à altura], quatro anos atrás ele estava com 12 anos. Ele fez uma arte, coisa boba [balança os ombros]. Mais o que eu ouvi no colégio e o cansaço. Eu dei uma surra nele. Nem era para tanto. Eu sou muito braba. Só que nesse dia eu mesma vi que não era para tanto. Eu vi que eu estava no meu limite. Eu fiquei essas duas ou três semanas [não se lembra do período muito bem]. Acho que não chegou a três. Eu parei de estudar novamente, não fui mais. Chegava em casa estressada, com dor de cabeça, me sentindo mais burra impossível. Chegava em casa quase chorando, assim. Fico meio emocionada quando eu lembro [seus olhos marejam de lágrimas, uma lembrança dolorosa é remetida a essa primeira tentativa de retomar a escolarização]. (Entrevista realizada em 9 de dezembro de 2016; Carol têm 43 anos, porto-alegrense, mãe de dois filhos). 
Na fala de minha colega, amiga e interlocutora, ressurge muito do que já havíamos conversado em outros momentos. Decidir pelo abandono é tão doloroso que essa ação põe em jogo um passado difícil para escolarização das pessoas que passam cotidianamente pela Educação de Jovens e Adultos. Vergonha de abandonar mais uma vez, o estresse de trabalhar para custear sua sobrevivência, e, ainda, a sensação de "incapacidade e burrice" que é interpretada a partir do ato de desprezo de um professor qualquer.

O corpo é remetido à "brabeza" de Carol ao descontar, sem motivo aparente, sua frustração de um dia extenuante no filho pequeno. Lembro-me desse momento na entrevista. Seus olhos marejavam, sentia-se culpada pelas pancadas que deu em seu filho, viu-se no lampejo daquele instante como uma pessoa descontrolada (fora de si). Disse-me, também, que não mediu a força do castigo (fora do corpo) e no derradeiro golpe, parou e pensou no que estava fazendo; refletindo sua ação, decidiu abandonar o que lhe fazia um mal-estar psicossocial, justamente, sua tentativa de retornar aos estudos.

Volto-me agora para as dimensões de desânimo e cansaço como realidades emocionais postas em jogo na evasão. Essas clivagens emocionais são sub-repticiamente mencionadas na forma de dores musculares, uma dor de cabeça episódica, ou até uma preguiça desanimadora que percorre todo o corpo. Em algumas ocasiões, sentado em um dos bancos que fica próximo à recepção ou Serviço de Atendimento Escolar (SAE), ouço conversas informais. Momentos antes de entrarmos em sala, um dos estudantes, com quem eu interagia, comenta:

Esses dias mesmo... Andei pensando em parar. Não estou aprendendo nada, pelo menos que eu consiga entender, como aquele negócio de e-mail e vestibular. Eu acordo às $5 \mathrm{~h} 30$ da manhã, termino de trabalhar às $5 \mathrm{~h} 30$ da tarde e estou aqui. Não sei se vou fazer o Enem, só sei que estou cansado, com uma dor na lombar. (Diário de campo, segunda-feira, 3 de abril de 2017).

O registro da experiência da evasão é constituinte então de diversos interstícios emocionais: as rotinas extenuantes que são tanto corporalmente distribuídas quanto vivencialmente pensadas. Parar implicava querer se cansar apenas para o trabalho, não para os "estudos". Aquele que evade, imagino, recolhe esses termos (ou graus perceptivos) para compreender sua própria 
experiência sensorial do que significa ter um corpo presente na aprendizagem escolar.

\section{Fragmento de um romance de uma (im)possível deserção}

As pessoas são nomes na lista de presença, algumas nunca vieram para aula. São chamadas como fantasmas, pelo hábito de repetição dos nomes e sobrenomes que os docentes adquiriram em anos de prática. Disso, depreendo que a dimensão de desistência também se constitui como um fato a priori que diz respeito às possibilidades mesmas de iniciar um caminho de retorno à escolarização. As dificuldades de retomar os estudos já foram tematizadas com um considerável grau de excesso no campo da educação: se enfatizou, por exemplo, a repetência em sua interligação com a evasão, o alcance das políticas educacionais, a gravidez na adolescência e não menos as condições socioeconômicas (Lüscher; Dore, 2011). Mas e se considerarmos as cargas afetivas que essas "causações" produzem na vida dos sujeitos? O que teríamos de real nos sentidos e sensações no corpo de alguém que se propõe, mesmo em pensamento, a evadir?

Neste tópico, gostaria de fazer uma distensão à interpretação que venho desenvolvendo. Em primeiro lugar, refaço um pouco do escopo da análise sobre a evasão - agora sinonimamente pensada como uma deserção. Escolhi essa nova palavra para poder recomeçar a dizer tudo o que tinha dito antes. Decidi então olhar para a evasão no registro de uma política emocionalmente moral, que se faz na dramatização de um romance enquanto metáfora social optada para descrever o que uma das minhas interlocutoras relatou.

Considerando a inspiração na perspectiva narrativa, Beatty (2010) adverte que as emoções se contam por histórias. Assim, talvez para sair de uma posição confortável, tento transcrever um diálogo que ocorreu com uma interlocutora improvável naquele momento, cujo nome é Cristina. A conversa vem investida de uma mistura emocional. O que se segue é a textualização de dados espalhados no meu diário de campo, de várias outras falas que são sintetizadas pela singularidade de Cristina.

- Mas, sei, Alef, dos motivos porque não estou, reconheço as minhas ausências.

- Semestre passado eu te vi poucas vezes. 
- Minha mãe estava no hospital, estava no tratamento intensivo, não pude participar das aulas como eu queria. Eu pego dois ônibus para chegar aqui, enfrento a noite sozinha para chegar ao lugar em que eu moro. Quando chego, Alef, vou ver se meu filho está bem, se ele comeu. Vou preparar o almoço e a janta de amanhã. Tomo banho, como alguma coisa e vou dormir. Nesse meio tempo já é uma hora da manhã.

- E você trabalha só em casa?

- Não. Eu acordo sete horas da manhã, tomo banho para chegar ao trabalho às oito horas em ponto. Fico lá até às seis da tarde e depois venho para cá. No semestre passado eu quase não comia com minha mãe no hospital, só café e cigarro. Porque dá para notar que eu fumo quando estou nervosa.

- E hoje? Está nervosa com a apresentação?

- Eu quero fumar, vem comigo até o portão [no portão de entrada, entre a fumaça cinza e o gesto de retomada do fôlego, ela tece suas considerações].

- Eu queria fazer medicina, meu sonho era ser médica, mas tive que parar de estudar, engravidei. Eu me achava boa em química, biologia, física, ciências em geral. Gostava muito dessas matérias. Eu parei no fundamental, tentei voltar outras vezes, mas é ruim com filho pequeno. O difícil mesmo é achar alguém que cuide. Conheci o Colégio de Aplicação por acaso [não falou mais nada sobre esse acaso].

- E o teu Projeto de Investigação [PI $\left.{ }^{6}\right]$ ?

- Eu nem sei como vou apresentar, sabe? Minha equipe toda não veio e eu faltei muito no semestre inteiro. Pensei até em desistir, era desgastante dividir o tempo entre escola, trabalho e hospital. Estou muito cansada e apresentar na frente de todo mundo é complicado. Uma coisa é você saber, outra é você explicar o que você sabe.

- Não gostou do teu PI?

- Gostei, não é isso. Acho que é porque eu não entendo as coisas. Eu sou ariana, Alef, sou impulsiva. Nesse semestre que está acabando eu vinha para aula de sexta-feira morrendo de cansaço e preocupação. Minha mãe estava internada, e eu vinha para cá e eu era um pé batendo. Sabe o que é isso? Um pé batendo

6 O PI é uma modalidade curricular do Colégio de Aplicação em que os estudantes são introduzidos nas práticas comuns de pesquisa científica. Eles escolhem um projeto de um ou mais professores, e estudam temáticas específicas por meio de uma pedagogia diferenciada, que inclui oficinas, formas de pesquisar na internet e discussões temáticas. 
naquela aula. Era a porra de um pé batendo. Acho que deveríamos escolher que disciplina fazer, não queria fazer música, estava cansada. Nós estávamos ensaiando aquele livro que virou filme... Do Ariano Suassuna?

- O Auto da Compadecida?

- Isso mesmo, tu estavas lá.7 Viu, era isso que eu não entendendo. Você não acha que essas coisas deveriam ser opcionais?

- Não sei.

- Está na hora, vai começar as apresentações. Vamos, Alef, vai ser no teatro, eu acho.

(Diário de campo, quarta-feira, 14 de dezembro de 2016).

O termo "deserção" tem uma forte conotação política, o desertor é aquele que escolheu desistir de um compromisso. De maneira que procuro ampliar a narração das emoções para também entendê-las na fronte de vários compromissos pessoais que se erguem na existência de cada estudante. Nesse pequeno excerto sintético de notas de campo, confesso que me deparei com a dureza do retorno à escola, que por vezes, se traduz um sentimento de absurdo: "A porra de um pé batendo." A ideia de completar o ensino médio também carrega em si, mesmo difusamente, a retórica das possibilidades de emprego e ascensão social. Porém, quanto mais se deparam com dificuldades e se reconhecem a partir de suas faixas etárias, alguns alunos e alunas se desiludem com sua decisão. Perdendo a força motivacional da mobilidade econômica, as(os) estudantes decidem apenas continuar.

Lembro-me que, certa vez, sentado na recepção do Colégio de Aplicação, uma moça sentou-se ao meu lado e perguntou o que eu fazia indo às aulas da turma dela. Respondi que tinha vontade de entender os significados de voltar a estudar. Ela tinha um cabelo liso e castanho, os óculos de lentes quadradas e uma voz plácida. Olhou-me e respondeu:

Eu voltei a estudar por uma vida melhor. Meu pai só estudou até o fundamental e ele não ligava muito para o estudo. Para ele deveríamos [todos os cinco irmãos]

7 A referência diz respeito a um conjunto de aulas específicas em que os estudantes participavam de uma gravação de áudios para a peça Auto da Compadecida. As atividades ocorreram durante as aulas de música e se constituíam nos exercícios de captação de som, similar aos procedimentos de sonoplastia. 
estudar obrigatoriamente até o fundamental. Fazer o ensino médio era opcional. Quem não queria estudar, que fosse trabalhar. Foi preciso três casamentos e uma hérnia de disco para que eu voltasse a estudar. (Diário de campo, sexta-feira, $1^{\circ}$ de julho de 2016).

A referida hérnia causava-lhe dores, e ela demorou quase um ano para se recuperar. A decisão de voltar foi antecedida por experiências de trabalho cansativas. Essa moça, com quem conversei, tinha 38 anos, e disse-me também que trabalhou durante dez anos como costureira, de sol a sol. Foi seu terceiro cônjuge que, vendo uma faixa na Avenida Bento Gonçalves sobre o CAp., pediu que ela se inscrevesse no edital. Em outro encontro, contou-me que hoje valorizava os estudos, mas sabe que suas chances de conseguir um emprego melhor são poucas. Confidenciou-me, ainda, gostar de química e que pretende prestar vestibular para essa área. Ela estava decidida, iria continuar.

\section{O sentido contrapolítico da evasão}

Visitei nos tópicos anteriores alguns dos principais desdobramentos que a evasão produz, implicando-a nos registros emocionais e corporais para entendê-la um pouco além de seu espectro negativo para as políticas educacionais. Resta indagar: o que os evadidos querem dizer a partir de seu abandono? Poderia, sem mais delongas, afirmar que "evadir" é um verbo de resistência, considerando os conselhos de Foucault (1995). Compreende-se, dessa forma, que o abandono e o retorno à escola funcionam enquanto um modo de subjetivação. A consequência reflexiva desse aspecto é que essa experiência subjetiva se traduz numa dimensão agentiva que as e os estudantes potencializam em suas tentativas de se escolarizarem, ou seja, para fins analíticos os sujeitos produzem, nesse tensionamento, a sua escolarização.

Entretanto, não tomo parte da ideia de resistência porque essa noção ancora-se prioritariamente em classificar a relação dos modos de existência do sujeito com um discurso que os (in)forma de fora para dentro, simulado, por exemplo, nas práticas de si e tecnologias do eu. Quando os estudantes da EJA voltam a estudar, eles não estão "resistindo", e sim moldando pelos seus próprios fragmentos de experiência escolar o entendimento que desenvolveram 
sobre o que é a escola e para que ela serve. A questão é que o conceito de resistência remete a agência fundamentada na emergência do poder, mas, como esclarece Mahmood (2006, p. 133, grifo da autora) o agir pode ser pensado também "como uma capacidade para a acção criada e propiciada por relações de subordinação [...]".

Nomeio como contrapolítica essa dimensão encontrada no meu trabalho de campo, pois compreendo que o alunado evadido faz de sua ausência um movimento real e duradouro de contestação às formas de existência da própria instituição escolar e das políticas que a subsidiam. Os estudantes, ao fazer aparecer nos diários de classe, eventos escolares e taxas estatísticas seu abandono, despertam os olhares dos docentes e dos gestores governamentais para sua decisão.

Essa contrapolítica de um corpo ausente, fundamentada no abandono escolar repetido e nas faltas que se acumulam nos registros documentais do professorado, multiplica-se como uma crítica não dita, inconfessa. O corpo discente produz por esse movimento, uma mobilização sutil e engajada emocionalmente com sua própria maneira de pensar a escola: a escolarização é minha, portanto, também escolho como e quando vivenciá-la, ou não. Essa produção da escolarização pela evasão se espraia nas dúvidas que acalentam sobre a volta aos estudos.

Evidentemente, pode-se perguntar sobre como a escola dissemina seus discursos e é por eles destilada. Assim, por qual maneira os alunos e alunas a demarcam nas suas trajetórias sociais? Para responder, é necessário avaliar a multiplicidade de sentidos presentes em um ato solitário que se soma a tantos outros atos, também solitários, que apontam uma distorção na hierarquia do discurso - a evasão, penso, é uma crítica simétrica subjetivada. Os alunos e alunas modelam sua escolarização tanto quando estão dentro como quando estão fora. Tornam visível e ao mesmo tempo indefinível o que é fora e o que é dentro, atendo-se à opacidade criativa de suas existências.

Em determinada noite, um pouco depois de sairmos da aula, fui com dois colegas para um boteco. Chegando lá, tomamos algumas cervejas e discutimos sobre a escola. Expus-lhes minha hipótese acerca das origens emocionais da evasão e dos desdobramentos que nutria. Eles foram taxativos em suas colocações: "É preciso ver o que se repete, se for igual a quando você estudava, sim. Você abandona mesmo. Mas, se é diferente você continua." Seu alerta era simples, ninguém repete a mesma escolarização. 
Quando os estudantes se veem reproduzindo uma experiência similar eles optam por abandonar. Então, no diálogo que travávamos na mesa entre uma linguiça e outra, apareceram esses "elementos repetidos". Pelo que foi mencionado, as dificuldades e a sensação de desengajamento são frutos de sentimentos de déjà-vu. Essa repetição compreendida como "automática" promove para o alunado uma espécie de eclipse em seus processos de aprendizagem, tornando-os opacos e refratários às experiências anteriores.

Essa luta contra a repetição da experiência permite apreender outras modelizações que os estudantes traçam para tornar factível a decisão de evadir. $\mathrm{Na}$ conversa, continuamos a examinar os aspectos da evasão. Mencionei que o cansaço, quando acumulado no corpo, em várias situações, é fundamental para compreender o abandono. Considerava-o um elemento central, na medida em que me explicava um corpo senciente à aprendizagem. Os meus colegas concordaram, e acrescentaram suas considerações: "O cansaço é isso mesmo que você está dizendo. Ficamos cansados, trabalhamos e estudamos com um cansaço no corpo. Não sei se eu te disse, às vezes de manhã quando acordo eu esqueci tudo o que o professor passou na aula. Olha, está vendo, o cansaço apaga alguma coisa." O apagamento produz a descrença em torno daquilo que realmente se aprende e do que vale a pena aprender. Por vezes tal questionamento se sobreleva na decisão pelo abandono.

Transcorreram inúmeras conclusões nessa conversa. Mostrou-se um bom momento de fazer os apontamentos e sugestões fornecidas pelos estudantes, revelando o caráter das sociabilidades que eram traçadas em relação a mim. Suas confidências serviram para embasar e reformular alguns dos argumentos presentes no texto, com destaque para esse looping emocional que torna a evasão algo difícil de ser pensado quando não é sentido. Sentido enquanto realidade expressiva, constante, que atravessa (e constitui) as relações, da mesma forma que o luto explicitado por Renato Rosaldo (1989, p. 175, tradução minha), ao compreender que o etnógrafo é um "sujeito posicionado".

Na deriva desses sentimentos e no seu uso reflexivo, os estudantes vão elaborando seu trafegar pela escolarização retomada. Assim, evadir pode significar que em outro lugar e hora talvez esse estudante volte mais uma vez a estudar. O "nomadismo" escolar provocado pelo abandono e pela retomada dos estudos faz-se por meio de uma constante reconsideração sobre como se sentem em relação à escola e à aprendizagem, fazendo da evasão uma decisão 
emocional-reflexiva e uma ferramenta de contestação. Algo que conceitualmente pode remeter ao devir definido por Deleuze e Parnet (1998, p. 3): “Devir é jamais imitar, nem fazer como, nem ajustar-se a um modelo, seja ele de justiça ou de verdade." Portanto, a escolarização e a evasão estão em constante devir.

\section{Considerações finais}

Um dos principais aspectos do trabalho etnográfico com as emoções, ressaltados por Beatty (2014), é a recuperação de dimensões imponderáveis na experiência. Elas operam nas tramas dos fatos, os constituem como vivência e espalham-se em sentimentos compartilhados entre os próprios sujeitos e o etnógrafo. As emoções, seguindo Beatty (2014), formam-se entre vestígios de encontros passados - a experiência emocional é transcrita enquanto uma história incorporada com outras. Parte desse argumento foi desenvolvida ao longo do texto, objetivando transpassar aos leitores a problemática da evasão pelo modo como os materiais etnográficos a apreendiam. Além do mais, os diálogos e conversas com os interlocutores produzem, quando coligados, uma densidade imersiva perceptível, em que os sentimentos são trazidos à tona por exemplos pequenos, fragmentos de sensações e compromissos pessoais que estão na base do fenômeno analisado.

Optei por enfatizar as dimensões política e contrapolítica do abandono escolar pelo entendimento de que esse acontecimento prático envolve sujeitos com diferentes cargas de complexidade. As diferenças não podiam ser cooptadas por ideias de uma coerência interna, indissolúvel, entendida enquanto causa operandi única. Demonstrar as ambivalências em suas expressividades sentimentais tornou mais inteligível a proposta que o texto explora: as gêneses emocionais da evasão. São esses conjuntos de afetos irresolutos, que se abrem e se fecham em diferentes backgrounds morais, encaminhando e informando as atitudes de cada indivíduo - nessa situação específica, o retorno à escola ou seu abandono.

De fato, poderia ter começado com uma introdução mais clara sobre o que denomino como afetos sem solução. Para mim, esses afetos são emoções corporificadas (Csordas, 2008) que redundaram no jogo corpóreo dos sentidos - 0 que pode ser observado quando os estudantes explicam o que é o cansaço, a preguiça, o desânimo e as dores pontuais surgidas após um dia de trabalho. 
O leitor deve estar se perguntando: não existem "bons sentimentos" no retorno à escolarização? A resposta é positiva. Sim, eles existem e são formalizados pelas mesmas dinâmicas morais que embasam a evasão. Conforme comentei logo no início da minha reflexão, o abandono desperta um caráter ético. A ética de uma convivência interrompida só é possível por conexões de amizade e companheirismo, por desejos de compartilhar e significar experiências conjuntamente com esse outro "desaparecido".

Utilizei o filósofo Emmanuel Lévinas para compor esse argumento ético e, por isso mesmo, político, do abandono escolar. Lévinas (1987) admite que a ética, na forma de uma interpelação ao ser, é o que se define por uma filosofia primeira, anterior à própria ontologia. $\mathrm{O}$ debate exposto em sua perspectiva serviu para articular os sentimentos de amizade (Rezende, 2002) na maneira de relações constituintes da alteridade, também constitutivas de outras emoções associativas à convivência com esse outro: alegria, felicidade, mágoas. Mas, como os fins interpretativos do texto demandam que alguns recortes sejam contemplados, decidi ater-me ao lado "negativo" (no sentido fotográfico) da evasão, pois essa maneira me aproximava da forma como os interlocutores me faziam sentir sobre seus relatos.

De maneira geral, apenas uma parte ínfima do material etnográfico foi abordada ao longo da trama narrativa composta a partir do diário de campo, situação compreensível pelo fato de que a pesquisa ainda não acabou. Provavelmente outros acontecimentos irão destoar da análise proferida aqui, em particular, ao escopo maior que a minha etnografia propõe: os processos de aprendizagem na Educação de Jovens e Adultos. Misturei a abordagem contextualista proposta por Abu-Lughod e Lutz (1990) no campo da antropologia das emoções com a narratividade etnográfica argumentada por Beatty (2010) para reconciliar dados que percebi como dispersos nas minhas anotações. Espero não ter confundido o leitor pela maneira como selecionei as inspirações de cada perspectiva. Também ouso reafirmar o papel decisivo da observação participante no lidar com esses fatos emocionais, que se implicam na convivência de longo prazo do pesquisador - tomamos parte das emoções que interpretamos. Com algum grau de diferenciação, elas se tornam parte, às vezes camufladas, de nossas etnografias, de nossas topografias sentimentais.

A fim de concluir a reflexão sobre a experiência emocional que torna a deserção escolar algo profundamente importante, nos termos de um fenômeno 
que intercepta a vida estudantil de várias pessoas, gostaria de me remeter às habilidades transformativas e transitivas que os sentimentos desenvolvem. Uma escolarização "tardia" pode sim ser transformada pelo acionamento de outras experiências como algo extremamente positivo: formas outras de devir, criar novas aprendizagens, reencontrar amigos, enfrentar antigas dificuldades e ressignificar velhos acordos íntimos servem para promover torções em traumatismos afetivos anteriores. Sigo com a percepção de que são os sujeitos que fazem a escolarização; geram em seus laços com o mundo novas possibilidades. No suor de cada dia, no frio de inverno, nos ventos e chuvas que deixam a ida à escola mais complicada, os sujeitos fortalecem-se emocionalmente e seguram no corpo as marcas de suas decisões.

\section{Referências}

ABU-LUGHOD, L.; LUTZ, C. Introduction: emotion, discourse and the politics of everyday life. In: LUTZ, C.; ABU-LUGHOD, L. (ed.). Language and the politics of emotion. Cambridge: Cambridge University Press, 1990. p. 1-23.

BARBALET, J. M. Why emotions are crucial. In: BARBALET, J. M. (ed.). Emotions and sociology. Oxford: Blackwell, 2000. p. 1-9.

BEATTY, A. How did it feel to you? Emotion, narrative and the limits of ethnography. American Anthropologist, v. 2, n. 3, p. 430-443, 2010.

BEATTY, A. Anthropology and emotion. Journal of the Royal Anthropological Institute (N.S.), v. 20, p. 545-563, 2014.

CSORDAS, T. Corpo/significado/cura. Porto Alegre: Editora da UFRGS, 2008.

DELEUZE, G.; PARNET, C. Uma conversa, o que é e para que serve?. In: DELEUZE, G.; PARNET, C. Diálogos. São Paulo: Escuta, 1998. p. 2-29.

FOUCAULT, M. Microfísica do poder. Rio de Janeiro: Graal, 1995.

INGOLD, T. Conociendo desde dentro: reconfigurando las relaciones entre la antropología e la etnografía. Etnografías Contemporáneas, v. 2, n. 2, p. 218-230, 2015.

JENKINS, J. H.; VALIENTE, M. Bodily transactions of the passions: el calor among Salvadoran women refugees. In: CSORDAS, T. Embodiment and experience: the existential ground of culture and self. Cambridge: Cambridge University Press, 1994. p. 163-182. 
LE BRETON, D. As paixões ordinárias: antropologia das emoções. Petrópolis: Vozes, 2009.

LÉVINAS, E. Entre nós: ensaios sobre a alteridade. Petrópolis: Vozes, 1987.

LÜSCHER, A. Z.; DORE, R. Política educacional no Brasil: educação técnica e abandono escolar. Revista Brasileira de Pós-Graduação, Brasília, v. 8, n. 1, p. 147-176, 2011.

MAHMOOD, S. Teoria feminista, agência e sujeito liberatório: algumas reflexões sobre o rivalismo islâmico no Egipto. Etnográfica, Lisboa, v. 10, n. 1, p. 121-158, 2006.

MAUSS, M. A expressão obrigatória dos sentimentos (1921). In: CARDOSO DE OLIVEIRA, R. (org.). Marcel Mauss. São Paulo: Ática, 1979. p. 147-153.

NERI, M. C. (coord.). O tempo de permanência na escola e as motivações do sem-escola. Rio de Janeiro: FVG/IBRE, CPS, 2009. Disponível em: http://www.cps.fgv.br/cps/tpemotivos/. Acesso em: 28 abr. 2017.

REZENDE, C. B. Mágoas de amizade: um ensaio em antropologia das emoções. Mana, Rio de Janeiro, v. 8, n. 2, p. 69-89, 2002.

ROSALDO, R. Grief and a headhunter's rage. In: ROSALDO, R. Culture and truth. Boston: Beacon Press, 1989. p. 177-178.

Recebido: 04/04/2018 Aceito: 05/02/2019 | Received: 4/4/2018 Accepted: 2/5/2019 